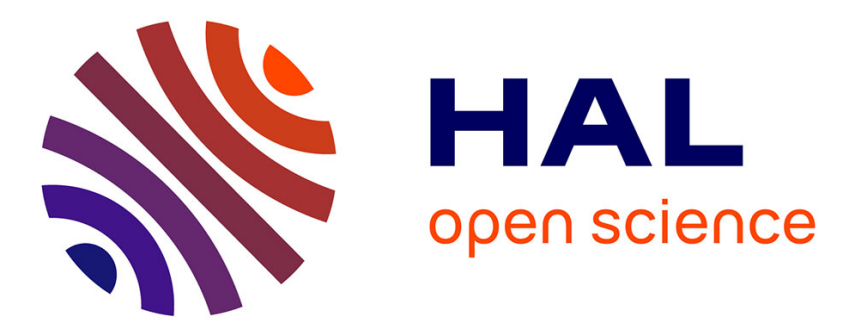

\title{
Document supply of grey literature and open access: ten years later \\ Joachim Schöpfel
}

\section{To cite this version:}

Joachim Schöpfel. Document supply of grey literature and open access: ten years later. Interlending and Document Supply, 2015, 43, pp.84 - 93. 10.1108/ILDS-02-2015-0004 . hal-01395746

\section{HAL Id: hal-01395746 \\ https://hal.univ-lille.fr/hal-01395746}

Submitted on 11 Nov 2016

HAL is a multi-disciplinary open access archive for the deposit and dissemination of scientific research documents, whether they are published or not. The documents may come from teaching and research institutions in France or abroad, or from public or private research centers.
L'archive ouverte pluridisciplinaire HAL, est destinée au dépôt et à la diffusion de documents scientifiques de niveau recherche, publiés ou non, émanant des établissements d'enseignement et de recherche français ou étrangers, des laboratoires publics ou privés.

\section{(c)(1)}

Distributed under a Creative Commons Attribution| 4.0 International License 


\title{
Document Supply of Grey Literature and Open Access: Ten Years Later
}

\author{
Joachim Schöpfel, GERiiCO laboratory, University of Lille 3, France
}

\begin{abstract}
Purpose - The paper aims to investigate the impact of the open access movement on the document supply of grey literature.

Design/methodology/approach - The paper is based on a comparative survey of five major scientific and technical information centres: The British Library (UK), KM (Canada), INIST-CNRS (France), KISTI (South Korea) and TIB Hannover (Germany).

Findings - The five institutions supplied less than 1.8 million supplied items in 2014, i.e. half of the activity in 2004 (_55 per cent). There were 85,000 grey documents, mainly conference proceedings and reports, i.e. 5 per cent of the overall activity, a historically low level compared to 2004 ( 72 per cent). At the same time, they continue to expand their open access strategies. Just as in 2004 and 2008 , these strategies are specific, and they reflect institutional and national choices rather than global approaches, with two or three common or comparable projects (PubMed Central, national repositories, attribution of DOls to datasets, dissertations and other objects). In spite of all differences, their development reveals some common features, like budget cuts, legal barriers (copyright), focus on domestic needs and open access policies to foster dissemination and impact of research results. Document supply for corporate customers tends to become a business-to-business service, while the delivery for the public sector relies more, than before, on resource sharing and networking with academic and public libraries. Except perhaps for the TIB Hannover, the declining importance of grey literature points towards their changing role - less intermediation, less acquisition and collection development and more high-value services, more dissemination and preservation capacities designed for the scientific community needs (research excellence, open access, data management, etc.).

Originality/value - The paper is a follow-up study of two surveys published in 2006 and 2009.
\end{abstract}

Keywords Document supply, British library, Grey literature, CISTI, INIST

Paper type Research paper

\section{Introduction}

The last decade was a period of major changes and challenges for academic libraries and scientific and technical information (STI) centres. The handling of grey literature may be a good indicator for these transformations in so far as it is not driven by the financial interests of commercial publishing. What STI centres do with grey literature reveals strategic choices as well as public policies regarding scientific documentation.

Ten years ago, in 2005, we conducted a first survey on the handling of grey literature by five major document suppliers ${ }^{1}$, with special attention to holdings, services and projects in the emerging environment of open access (Boukacem-Zeghmouri \& Schöpfel 2006). At that time (figures from 2004), the supply of conference proceedings, reports, dissertations etc. was more or less a small part of the overall activity but the survey revealed different and divergent approaches and developments, especially regarding open access projects related to grey literature.

A follow-up study with the same "big five" STI centres conducted four years later confirmed these differences. In 2008, the five centres supplied together 2.45 million items, with nearly 250,000 grey literature (9\%), a slight increase in percentage compared to the first survey. Based on the 2008 statistics, we distinguished three situations:

"(a) High-level supply, low proportion of grey material (British Library). (b) Medium-level supply, low proportion of grey material, especially conference proceedings (CISTI, INIST, KISTI). (c) Medium-level supply, significant proportion of grey material, especially reports (TIB)" ((Schöpfel \& Prost 2009 p.187). The supply of dissertations was more or less insignificant.

Each STI centre had started carrying out its own open access strategy. Some were engaged in national repository projects, in the field of dissertations (British Library, KISTI), scientific publications (CISTI) and research reports (TIB). Other initiatives were limited to a specific

\footnotetext{
${ }^{1}$ The British Library (UK), CISTI (Canada), INIST (France), KISTI (Korea) and TIB Hannover (Germany)
} 
research domain (UK PubMed Central hosted by the British Library) or to service provision based on partnerships and conventions (INIST). The development of grey collections was generally linked to these open access strategies, e.g. deposit of grey items, digitization of print documents and metadata harvesting, often together with other libraries and document suppliers (op cit, p.188). Beside open repositories, we identified two other common features: the development of document supply as a long tail service, and the interest for primary research data (e-Science).

Development comprises both continuity and change. Open access has become an important part of scientific communication and institutional repositories and open journals are here to stay $^{2}$. Scientific institutions, funding bodies, governments and international organisations have established open access policies or intend to do so. At the same time, academic libraries and public STI centres have to cope with two other major challenges, namely research data management and budget restrictions ${ }^{3}$.

After a general review on studies on open access and document supply published last year (Schöpfel 2014), we will focus once more on grey literature, for the same reasons as ten years ago: grey holdings and related services need particular investments and efforts and at the same time, grey material is increasingly available on the Web. For both reasons, grey literature may be a sensitive indicator for the evolving strategies and policies of STI centres.

We can add one last word on grey literature. In the following, this term will cover theses and dissertations, reports, conferences and working papers, as the most representative types of grey literature, defined as documents "produced on all levels of government, academics, business and industry in print and electronic formats, but (...) not controlled by commercial publishers i.e. where publishing is not the primary activity of the producing body" (Schöpfel \& Farace 2010) ${ }^{4}$.

\section{Methodology}

This second follow-up study largely reproduces the methodology of the former surveys, with the same sample as in the initial study:

- The British Library (BL) ${ }^{5}$

- The NRC's Knowledge Management Branch (KM), formerly the Canada Institute of Scientific and Technical Information (CISTI) ${ }^{6}$

- $\quad$ The French CNRS Institut de 1'Information Scientifique et Technique (INIST) ${ }^{7}$

- The Korean Institute of Scientific and Technical Information (KISTI) ${ }^{8}$

- The German National Library of Science and Technology at Hannover (TIB) ${ }^{9}$

In the past, what these traditional document suppliers had in common was a public mission to collect, preserve, archive and disseminate scientific information through a non-profit ILL and document supply service that is based on a mixed economic model with their income supplied both by public funding and their customers' fees. ILL and document supply networks without holdings and corporate, profit-based suppliers are excluded from the sample.

Also, the methodological approach is the same as our former studies:

\footnotetext{
${ }^{2}$ See Heather Morrison's report on 2014 growth indicators of the open access movement http://poeticeconomics.blogspot.ca/2014/12/2014-dramatic-growth-of-open-access-30.html

${ }^{3}$ For context information, see McGrath (2015)

${ }^{4}$ See Schöpfel (2011) for a new definition of grey literature.

${ }^{5} \mathrm{http} / / / \mathrm{www} \cdot \mathrm{bl} . \mathrm{uk} /$

${ }^{6}$ https://cisti-icist.nrc-cnrc.gc.ca/

7 http://www.inist.fr/

${ }^{8}$ http://en.kisti.re.kr/

${ }^{9}$ http://www.tib.uni-hannover.de/
} 
(a) We searched for open source information about the development, services and projects of the sample on the institutional websites, in activity reports and published articles. Some institutions are well documented, in particular the British Library and the TIB, others are less.

(b) We asked each institution for information on the following topics:

1. Figures on their grey document supply and ILL in 2014.

2. Comparison of these figures to the overall supply and ILL (\%).

3. The recent evolution compared to previous years.

4. Their projects in the area of grey literature.

5. Their open access projects.

6 . The impact on the collection of grey literature.

7. The impact on document supply (service offer, pricing).

8. The impact on the bibliographic control of grey literature (cataloguing, record data).

9. The impact on the information system.

(c) We communicated the data synthesis to the responding institutions for comments and validation.

The results are presented for each institution, followed by some comments.

The survey was conducted between December 2014 and February 2015.

\section{Findings}

The following section presents the main results for each institution based on the responses to our survey, as well as freely available information on the institutional websites, articles and reports. KISTI did not respond in due time so that for them our analysis is limited to open sources.

\section{The British Library}

The British Library was created in 1973, through the merger of different components such as the library of the British Museum, the British Patent Office Library, the National Central Library and the National Lending Library for Science and Technology at Boston Spa, the latter two becoming the British Library Document Supply Centre. In 2014 its rich holdings (115.5 million items ${ }^{10}$ ) contain 10.4 million reports in microform, 269,442 theses, 68.6 million patent specifications and other unconventional items ${ }^{11}$. The quality, uniqueness of the depth and breadth of the British Library holdings are highly valued by its users (Tessler 2013, p.59).

$90 \%$ of UK remote users are "totally satisfied" with the British Library Document Supply service. The document supply and monograph lending fulfilment rate is now $72 \%$. "Document Supply income continued to be the Library's principal source of commercial revenue but it experienced a further decline in demand and sales in challenging market conditions ${ }^{12}$. However, the implementation of a new orders management system and the introduction of differential pricing for items supplied from electronic content provided some positive news in the overall performance" (British Library 2014, p.28). A recent article states that "since 2000, when the service peaked at four million requests, demand has steadily reduced to the current 3/4 million requests" (Appleyard 2015). One of the reasons was the decision to cease the provision of "Library Privilege" to overseas users towards the end of

\footnotetext{
${ }^{10}$ For this and the following figures, see British Library (2014).

${ }^{11}$ Such as pamphlets etc., see for instance Egan \& Stevens (2011).

${ }^{12}$ For a general overview on UK interlibrary loan and the British Library document supply service see Appleyard (2010) and Johnson (2011)
} 
2011 , and to replace it with a licensed reduced royalty rate service to academic institutions overseas. The provision of services decreased by $9 \%$ between 2012/13 and 2013/14.

A recent report on the economic valuation of the British Library provides the following figures: "The Library's Document Supply services generated a total of $£ 6.7$ million in revenue during 2011/12, of which $£ 4.5$ million was sourced from UK customers. There are some 4,300 Document Supply customers in total, of which 2,164 are based in the UK" (Tessler 2013, p.24). The same report estimates the value which document supply customers attach to the service (replacement cost) for $2011 / 12$ at $£ 5.5$ million (p.28).

Dataset Programme: as a founding member of DataCite ${ }^{13}$, the British Library assigns Digital Object Identifiers (DOIs) to datasets produced by UK based research. So far, the British Library has registered more than 750,000 datasets ${ }^{14}$ (see also Wilkinson et al. 2010).

Grey document supply

The British Library does not distinguish between document supply of "grey literature" and other document supply, so they cannot provide any figures here. The supply of "grey literature" has been overtaken by open access and the availability of conference and report material on the web, and it is no longer treated as a category of library material for document supply purposes. In fact, as they mention in the survey, they do not use the term "grey literature" any longer because "it feels slightly out-dated".

Comparison with the overall supply

$\mathrm{n} / \mathrm{a}$

Evolution

$\mathrm{n} / \mathrm{a}$

Projects in the field of grey literature

All projects in the field of grey literature are related to $\mathrm{EThOS}^{15}$, the UK's national thesis service, which aims to maximise the visibility and availability of the UK's doctoral research theses. The BL is developing a national system of DOIs for UK theses and text and data mining (TDM) opportunities to help understand the benefits, opportunities and risks around TDM as it specifically applies to theses. The University of Bristol is leading a wider National Compound Collection project to extract chemical compounds from hundreds of UK theses, and the BL is working closely with both Bristol and the project funders, the Royal Society of Chemistry (RSC), to extract chemical compound information from UK theses to add to the open access ChemSpider database. Another project is about machine extraction of key law phrases and sentence structures from UK theses in the field of Law, to help build languagelearning tools for Law students. These TDM projects raise some questions:

- Are the desired theses in a location and format that make them suitable? For example, accessibility of the holding repository, file formats, and the ease with which sets of theses could be selected, for example by subject.

- How will the thesis content be used? Does a new copy need to be made for a project, and what copyright applies?

- For which purpose would the use be permitted? Does the new text mining copyright exception apply, or does the project need to seek permission from all rights holders?

- Will there be benefits to HE stakeholders?

Open access projects

EThOS aims to provide a national aggregated record of all doctoral theses awarded by UK Higher Education institutions and free access to the full text of as many theses as possible for

\footnotetext{
${ }^{13}$ International Data Citation Initiative, member of the International DOI foundation https://www.datacite.org/

${ }^{14}$ See http://stats.datacite.org/

${ }^{15}$ http://ethos.bl.uk/
} 
use by all researchers to further their own research. There are approximately 380,000 records relating to dissertations awarded by over 130 institutions. Around 140,000 of these (37\%) also provide access to the full text thesis, either via download from the EThOS database or via links to the institution's own repository. Of the remaining 240,000 records dating back to at least 1800, three-quarters are available to be ordered for scanning through the EThOS digitisation-on-demand facility.

Together with the European Bioinformatics Institute and the University of Manchester, the British Library delivers Europe PubMed Central ${ }^{16}$, providing access not only to more than three million full text articles but also to additional content including biological patents, clinical guidelines, dissertations, research and other reports, including 30 million abstracts.

The impact on the collection of grey literature

The major changes of the collection development - legal deposit of digital publications, web archiving and heritage acquisition - partly impact the collection of grey literature (Brazier 2012), (Green 2009), especially reports and theses. New reports in microform have not been received in 2013/14, as the subscription for this content has not been renewed. The $\mathrm{BL}$ does not manage reports and conference papers in any specific way since they consider that the vast majority are freely available via the web.

The impact on document supply

To respond to changes in the external environment and to challenging times for public sector institutions in the UK, the "Document Supply Futures" strategy in 2010 included the "re-engineering of business processes, building on a new e-commerce platform, which provides a modern, online, pay-as-you-go (PAYG) interface and an integrated, system-tosystem solution, using an API" and in 2013 the "introduction of tiered pricing, differentiating between the supply of scanned print and born digital material, bringing down the price to our customers and promoting greater use of electronic content" (Appleyard 2015).

The impact on the bibliographic control of grey literature

EThOS thesis metadata is free to harvest via the OAI-PMH data sharing protocol. Most thesis metadata is now harvested from the 100+ institutional repositories in the UK. Extensive de-duplication, normalisation and enhancement are done by EThOS at the BL before loading to EThOS. All EThOS data is also added to the BL catalogue, made available for harvesting by other resource discovery services and is indexed by Google Scholar. Some metadata is tied in with funding requirements (for example, sponsor body/funder; supervisor; project ID; author IDs). The BL is moving towards a national approach to applying DOIs to all UK theses, working with UK Higher Education. It is a key piece of metadata, which will make citation easier, unlock valuable data and research content hidden in the pages of $\mathrm{PhD}$ theses, and allow linking to the underlying research data held in different/various subject or institutional repositories.

The impact on the information system

In 2008, the British Library implemented PRIMO, the Ex-Libris search system, which provides Web 2 functionalities (tagging, adding reviews) and allows cross searching with other catalogues.

\section{National Research Council Canada: Knowledge Management Branch}

The Knowledge Management Branch $\left(\mathrm{KM}^{17}\right)$ was established in 1924 as the National Research Council Canada (NRC ${ }^{18}$ ) library at Ottawa, Ontario. In 1967, it officially became Canada's National Science Library. In 1974, it became the Canada Institute for Scientific and

\footnotetext{
${ }^{16}$ Europe PMC, former UK PMC http://europepmc.org/

17 https://cisti-icist.nrc-cnrc.gc.ca/

18 http://www.nrc-cnrc.gc.ca/
} 
Technical Intelligence (CISTI) and in 2011, was re-branded NRC's Knowledge Management Branch, bringing together the National Science Library mandate, with the NRC library and records services. Its mission is to contribute to an innovative economy by providing high value information and knowledge services in the areas of science, technology and health. Its holdings contain over 50,000 journal titles, more than 800,000 monographs and two million scientific and technical reports. KM does not collect theses or dissertations.

Until 2009, KM (as CISTI) was one of the most important global document suppliers. In 2010, it exited the international document delivery business to focus on serving Canadians. From that point its document-supply partner Infotrieve ${ }^{19}$ started providing access to the national science library collection on behalf of NRC. In addition KM is responsible for delivering a full suite of library, information management, and strategic intelligence services to NRC.

Grey document supply

In 2014, KM supplied 573 copies $^{20}$ from grey literature (conference proceedings). The satisfaction rate was $98 \%$. Though KM has many technical reports, the data indicates that no copies or loans of reports were issued from 2011-14. This is likely because reports are considered as books in the new Mobile Library system. Since 2009, KM has stopped collecting print materials and only acquires electronic materials, so standing orders for conference proceedings were all cancelled.

Comparison with the overall supply

The supply of conference proceedings accounts for $3.6 \%$ of the overall number of supplied items. As indicated above, until 2010 KM supplied orders submitted from Canadian and international clients. From 2010 on, they exited the international document supply business to focus on serving Canadian customers, which explains the low numbers. The estimated total number of supplied items in 2014 was 15,895 .

Evolution

Since 2011, the supply of grey items has decreased by $70 \%$ (42\% from 2013 to 2014). Compared to the overall tendency $(-58 \%)$, grey item requests have declined by $30 \%$. The satisfaction rate remained stable at around 96-98\%. Yet, the most important decline that has been registered is that compared to 2004 and 2008, the 2014 grey literature supply represents only $1-2 \%$ of the former activity level.

Projects in the field of grey literature

DataCite Canada ${ }^{21}$ data registration service provides Canadian data centres and libraries with a mechanism for registering research data and assigning digital object identifiers (DOIs) to them. This includes assigning digital object identifiers to grey literature. KM is the Canadian member organization of DataCite International. As of December 30, 2014, DataCite contains 30,598 datasets with DOIs assigned by KM, most of them in Life Sciences (DNA sequences and metadata) and from 2013.

Open access projects

KM's NRC Publications Archive (NPArC) ${ }^{22}$ makes NRC publications openly accessible which, besides providing metadata and full-text for peer-reviewed journal articles, also includes NRC reports and conference publications. As of December 302014 this repository includes 54,440 records, of which 13,269 (24\%) include full-text . This includes 6,486 NRC reports, 12,346 conference publications and some students' works. Additional reports have

\footnotetext{
${ }^{19} \mathrm{http} / / / \mathrm{www}$. infotrieve.com/ Infotrieve was acquired by the Copyright Clearance Center in November 2014 http://www.copyright.com/content/cc3/en/toolbar/aboutUs/newsRoom/pressReleases/press_2014/press-release14-11-06.html

${ }^{20}$ Extrapolated from cumulated figures January-November 2014.

${ }^{21} \mathrm{http}$ ://cisti-icist.nrc-cnrc.gc.ca/eng/services/cisti/datacite-canada/index.html

22 http://dr-dn.cisti-icist.nrc-cnrc.gc.ca/eng/home/
} 
been digitized and NRC is in the process of adding these to the repository. Print reports are gradually deteriorating and NRC is preserving access by depositing electronic copies in the NRC Publications Archive. The repository also contains 305 patent records. KM has established a policy requiring NRC researchers to deposit copies of their peer-reviewed publications and technical reports in NPArC. Today, the NRC Publications Archive is a publicly accessible single gateway to NRC's record of research.

KM has created a Digital Repository, a persistent archive for digital objects of all kinds. This new platform was created to host many different digital collections in a single environment, offering an improved interface which can search each collection separately or the entire repository at once. The digital repository offers new opportunities to publicly share materials that were previously unavailable. It is built on industry standard, open-source technologies making it both robust and flexible, and ensuring its long-term viability. New digital collections are planned and will be released, as they are ready. To make use of this improved infrastructure and to ensure sustainability, the NRC Publications Archive will move to this Digital Repository platform in 2015.

Knowledge Management partners with the Canadian Institutes of Health Research (CIHR) and the National Library of Medicine to provide a national repository, PubMed Central Canada (PMC), for peer-reviewed health and life sciences literature. As such it is a member of the PubMed Central International network. PubMed Central Canada provides free access to content, and it is one of the locations where CIHR funded researchers can deposit their publications, an obligation under CIHR's Policy on Access to Research Outputs.

The impact on the collection of grey literature

No impact.

The impact on document supply

No - other than the availability of content via the services described above.

The impact on the bibliographic control of grey literature

No specific developments.

The impact on the information system

In 2010, KM switched automated document delivery platforms, from Intellidoc to the Infotrieve Mobile Library system, with different procedures and statistics, which explains why $\mathrm{KM}$ is unable to report in the same way as they had been doing in the past. Yet, there is no impact of OA projects on the information system so far.

\section{The Institute for Scientific and Technical Information (INIST)}

Part of the French National Centre for Scientific Research (CNRS), the Institute for Scientific and Technical Information (INIST) was created in 1988 "to facilitate access to results from all fields of world research, promote scientific production and provide services to people in Higher Education and Research" ${ }^{23}$. Successor of two former Paris-based STM and SS\&H documentation centres, INIST has one of the largest collections of scientific publications in Europe, comprising journals and grey literature (reports, dissertations and proceedings).

Since the last survey, INIST has undergone fundamental changes. Acquisition of print collections and the production of the two main French databases PASCAL and FRANCIS were disrupted, and the focus is now on subscription to e-journals and e-books, on the acquisition of back-files and on the dissemination to Higher Education and Research via portals (CNRS portals, ISTEX platform). INIST also started to invest in the management and preservation of research data, as a member of the international consortium DataCite ${ }^{24}$.

\footnotetext{
${ }^{23} \mathrm{http}: / / \mathrm{www}$. inist.fr/? About-Inist\&lang=en

${ }^{24}$ http://www.inist.fr/?DOI-Assignment\&lang=en
} 
French ILL and document supply has shown a significant decline since 2000 (Schöpfel \& Gillet 2011) ${ }^{25}$. The INIST document supply service declined from 700,000 in 2000 to 120,000 in 2013. In 2010, INIST launched a new Web-based article-level and ordering platform called RefDoc with 54 million records and 178,000 journals from 1823 onwards $^{26}$. Yet, in December 2013 a court decision settled that the agreement with the French copyright agency CFC based on an opt-out model was not compliant with the French intellectual property law. After this decision RefDoc and the document supply service were suspended. Today, the INIST document supply has become a free of charge service for CNRS researchers and based on the CFC authorizations for the French Higher Education and Research organizations while the delivery to corporate or private customers has stopped completely. The legal basis will be an opt-in model, through an agreement with the CFC and licensing with publishers. However, much work has yet to be done (Gillet 2014).

Grey document supply (2012)

In 2012 INIST supplied a total of 1,900 grey items to its customers: 969 conference proceedings, 701 dissertations and 230 reports. 109 (27\%) dissertations were provided by backup libraries from other countries.

Comparison with the overall supply

These items represented $1.2 \%$ of the overall supply of 153,471 fulfilled requests.

Evolution

In the past, the proportion of grey literature in the INIST document supply has always been rather low, between 3\% (2004) and 3.5\% (2008). From 2012 to 2013, this percentage declined even more, falling to only $0.2 \%$ (187 items, mainly proceedings and reports). The reason for this near extinction of grey document supply was a decision in 2013 to stop all delivery of items without ISBN or ISSN, i.e. more or less all grey material and above all, the dissertations. This decision followed a very controversial debate in social media and public forums between librarians and authors about the INIST fee-based supply of documents that are or should be freely available in open archives. The reader may be reminded that the CNRS, the mother organisation of INIST, is also in charge of the national OA platform HAL.

Projects in the field of grey literature

INIST continues to host and develop OpenGrey ${ }^{27}$, the OA successor of the former SIGLE database. New sources and resources have been added to the database, with a growing number of links to the full text. For some items, the document is deposited and preserved on the OpenGrey server. The figures from December 2014 are: OpenGrey totals 1,014,821 records (+47\% since 2008), with 49,900 links to the full text (5\%, mostly French dissertations in medical sciences and UK theses, via imported EThOS metadata) and 323 preprints from the international conferences on grey literature ${ }^{28}$.

Furthermore, since 2008 the content of the INIST OA platform for French scientific and technical reports $\mathrm{LARA}^{29}$ has doubled, from about 1,000 to 2,000 reports issued from several institutions and holdings (deposits and retro-digitization). For a better visibility, a specific LARA section will be created in the HAL repository (CCSD).

Open access projects

In 2013, INIST made freely available its bibliographic records of the Répertoire d'Art et d'Archéologie (1972-1989) and of the Bibliography of Art database co-produced with the Getty Foundation (1990-2008). Today, 559,750 records in the history of art and archaeology

\footnotetext{
${ }^{25}$ For the former INIST document supply, see Gillet (2007) and (2008)

${ }^{26} \mathrm{http}: / / \mathrm{www} \cdot$ refdoc.fr/

27 http://www.opengrey.eu/

${ }^{28} \mathrm{http} / / /$ www.opengrey.eu/about/greyliterature?lang=en

29 http://lara.inist.fr/
} 
are disseminated on the OA platform OpenBibArt ${ }^{30}$, covering nearly four decades of international publications (1972-2008).

In 2013, in reaction to the controversial debate about INIST document delivery, RefDoc has been linked to other OA repositories. The French institutional archives HAL ${ }^{31}$, Persée ${ }^{32}$, Revue.org ${ }^{33}$ and Orbi $^{34}$, and an archive at the University of Liege, are harvested on a daily basis and linked with references already on RefDoc. The link to the OA article as a PDF is provided for users. In early 2015, PMC $^{35}$ will be linked to RefDoc.

The impact on the collection of grey literature

The acquisition of grey literature was suspended.

The impact on document supply

Limited to public Higher Education institutions and CNRS.

The impact on the bibliographic control of grey literature

$\mathrm{n} / \mathrm{a}$

The impact on the information system

INIST and ABES are working with academic libraries in the Ministry committee called BSN8 $^{36}$ (digital scientific library) to design a French end-user based document supply platform and new functionalities will be developed in RefDoc for document delivery to streamline the academic network.

\section{The Korean Institute of Science and Technology Informaton (KISTI)}

The Korean Institute of Science and Technology Information (KISTI) ${ }^{37}$ has been providing STI services since 1962 together with R\&D in the field of scientific communication. KISTI hosts the Korean STI portal called the National Digital Science Links (NDSL) ${ }^{38}$ with more than 80 million items, mostly journal articles and patent information including grey literature, such as conference proceedings, technical reports or trend analyses for the corporate and scientific sectors, although there are no theses or dissertations; this grey litersture is $10 \%$ of the total ingest in 2009, (Yoo, 2010). Moreover, NDSL contains links to more than 4.5 million scientific datasets, mainly in life sciences and chemistry.

The document delivery service run by KISTI (NIDS) supplies items from KISTI's own holdings $(83 \%)$, from Korean libraries $(6 \%)$ or from international suppliers (11\%). In 2008 there were 815,250 orders (Yoo 2010). 1\% of the items supplied from the KISTI holdings in 2008 were grey literature (reports, standards, dissertations). A STI centre with significant research activity, KISTI also produces grey literature, such as reports on the STI market, proceedings from events and other papers.

Grey document supply

$\mathrm{n} / \mathrm{a}$

Comparison with the overall supply

$\mathrm{n} / \mathrm{a}$

Evolution

n/a

Projects in the field of grey literature

\footnotetext{
${ }^{30} \mathrm{http}: / / \mathrm{www}$. openbibart.fr/

${ }^{31}$ https://hal.archives-ouvertes.fr/

${ }^{32} \mathrm{http}: / / \mathrm{www}$.persee.fr/web/guest/home

${ }^{33} \mathrm{http}: / /$ www.revues.org/?lang=en

${ }^{34}$ http://orbi.ulg.ac.be/?locale=en

${ }^{35} \mathrm{http} / / / \mathrm{www} \cdot \mathrm{ncbi} \cdot \mathrm{nlm} \cdot \mathrm{nih} \cdot \mathrm{gov} / \mathrm{pmc} /$

${ }^{36} \mathrm{http}: / / \mathrm{www}$.bibliothequescientifiquenumerique.fr/?lang=eng

${ }^{37} \mathrm{http} / / / \mathrm{en} \cdot k i s t i . r e . k r /$

${ }^{38} \underline{\mathrm{http} / / / \mathrm{www} . \mathrm{ndsl} \cdot \mathrm{kr} /}$
} 
In August 2008, KISTI became the national agency for the deposit and preservation of Korean R\&D reports and other unpublished papers. At the end of 2014, KISTI announced a research project with Elsevier for the content mining of KISTI's scientific and technical reports. From 2010 on, KISTI has developed an R\&D activity in the field of research data management and preservation and established a national Science Data Advisory Committee.

Open access projects

KISTI launched the national portal called Open Access Korea $(\mathrm{OAK})^{39}$ and hosts the OAK Central platform for 40 open access journals with more than 5,000 articles ${ }^{40}$. The OAK portal holds about 300,000 items, journal articles, monographs, multi-media etc., harvested from 23 institutional repositories and OA journals (Hwang et al. 2014).

The impact on the collection of grey literature

$\mathrm{n} / \mathrm{a}$

The impact on document supply

$\mathrm{n} / \mathrm{a}$

The impact on the bibliographic control of grey literature

$\mathrm{n} / \mathrm{a}$

The impact on the information system

KISTI built infrastructures for dissertations, reports, datasets (Hub of Large Scale Test Data Centre, launched in September 2010) and open access journals (XML full text workbench).

\section{The German National Library of Science and Technology Hannover (TIB)}

With its rich holdings of scientific and technical literature, patents and other material, TIB Hannover, Germany's National Library of Science and Technology, today ranks as one of the world's largest specialist libraries and one of the most efficient document suppliers in its subject areas. The TIB has been working closely with the academic library of the University of Hannover for over 40 years. In 2015, they will finally merge into a single institution with shared staffing, management and strategies. For the TIB, this merger will be the opportunity to develop its research activities in the field of library and information sciences (Rosemann 2013).

Based on evaluation and auditing, the TIB continues to develop open access to scientific information, national licences for journal and book collections, long term preservation, retrodigitization of heritage material and management of research data. In the field of document supply, the TIB together with two other special libraries, launched in 2008 a one-stop shop for corporate customers in the field of STM and economics called Goportis ${ }^{41}$, a portal with the potential to become the central gateway to networked document supply for both corporate and public customers (Meyer 2009).

(Rosemann and Brammer 2010) and more recently, (Brammer and Olf 2014) have provided an overview on the development of document delivery in Germany since 2003 and in particular, of the TIB document supply and interlibrary loan service. They show that document delivery requests decreased steadily from 2006 to 2012, falling from 480,000 to $210,000(-56 \%)$. The rate of satisfied requests remained stable, with $85-90 \%$ fulfilled orders.

On the campus, the quality of the local document supply service is appreciated (Neumann 2012). Like other academic libraries, TIB has started to transform its building and space into a user- and learning-friendly environment (Franzkowiak 2012).

Grey document supply

\footnotetext{
${ }^{39} \mathrm{http}: / /$ oak.go.kr/

${ }^{40}$ http://central.oak.go.kr/

${ }^{41}$ http://www.goportis.de/
} 
TIB supplied about 75,000 grey items in 2014. 26,000 have been delivered through traditional academic interlibrary loan, 49,000 via the TIB document supply service GetInfo and the subito network.

Comparison with the overall supply

These items represent $37 \%$ of the overall supply (202,000 satisfied requests). The percentage is higher for interlibrary loan (48\%) than for document supply (33\%).

Evolution

The overall document supply decreased by nearly $60 \%$ between 2004 and 2014 . Yet, even though the number of grey documents delivered decreased as well, their proportion increased steadily from $27 \%$ in 2004 to $37 \%$ in 2014.

Projects in the field of grey literature

$\mathrm{n} / \mathrm{a}$

Open access projects

Another initiative of the TIB is cooperative workshops for students and scientists to develop their information literacy, especially in the field of open access publishing (Luca \& Koch, 2014).

The impact on the collection of grey literature

$\mathrm{n} / \mathrm{a}$

The impact on document supply

The TIB increased existing cooperation with partners such as subito ${ }^{42}$ and the FIZ ${ }^{43}$ AutoDoc service in order to extend the offer of content and to deal with insufficient licences or rights management. The TIB also started to prepare a new document supply strategy called "TIB Full Text Supply 2020" that will take into account the decreasing demand for traditional document supply and legal barriers.

The impact on the bibliographic control of grey literature

$\mathrm{n} / \mathrm{a}$

The impact on the information system

Following the amendment of the German copyright law in 2008, a greater differentiation of orders was required by customer group, supplying country and form of delivery. "Therefore, the associated examination of licences and legally compliant delivery necessitated a software solution" (Brammer and Olf 2014, p.77).

\section{Discussion}

Document supply

Figures are incomplete, and not all are up to 2014. It is difficult therefore to get a clear idea of the actual number of requests fulfilled by the "big five". Yet, based on the published statistics, less than 1.8 million items were supplied, half that in 2004. This decrease is a general phenomenon, except for KISTI that increased from 300,000 to more than 600,000 orders. Moreover, for the BL, KM, INIST and the TIB the decrease accelerated from 2008 onwards. KM outsourced the document supply to Infotrieve (now the US based Copyright Clearance Centre) while INIST suspended the document supply and then limited it to the domestic HE and research sector.

\section{Grey literature}

It has become even more difficult to estimate the part of document supply of grey literature. The BL considers that the concept of grey literature does not make sense any longer. The KM management system processes one part of grey literature like published books, without distinction. INIST stopped the supply of grey literature, because of legal problems. A very prudent estimation is that in 2014, these document suppliers delivered

\footnotetext{
$42 \mathrm{http}: / /$ www.subito-doc.de/

${ }^{43} \mathrm{http} / / /$ autodoc.fiz-karlsruhe.de/
} 
together less than 85,000 grey documents, mainly conference proceedings and reports, i.e. 5\% of the overall activity, a historically low level compared to former years. This amount would be $28 \%$ of the 2004 grey document supply.

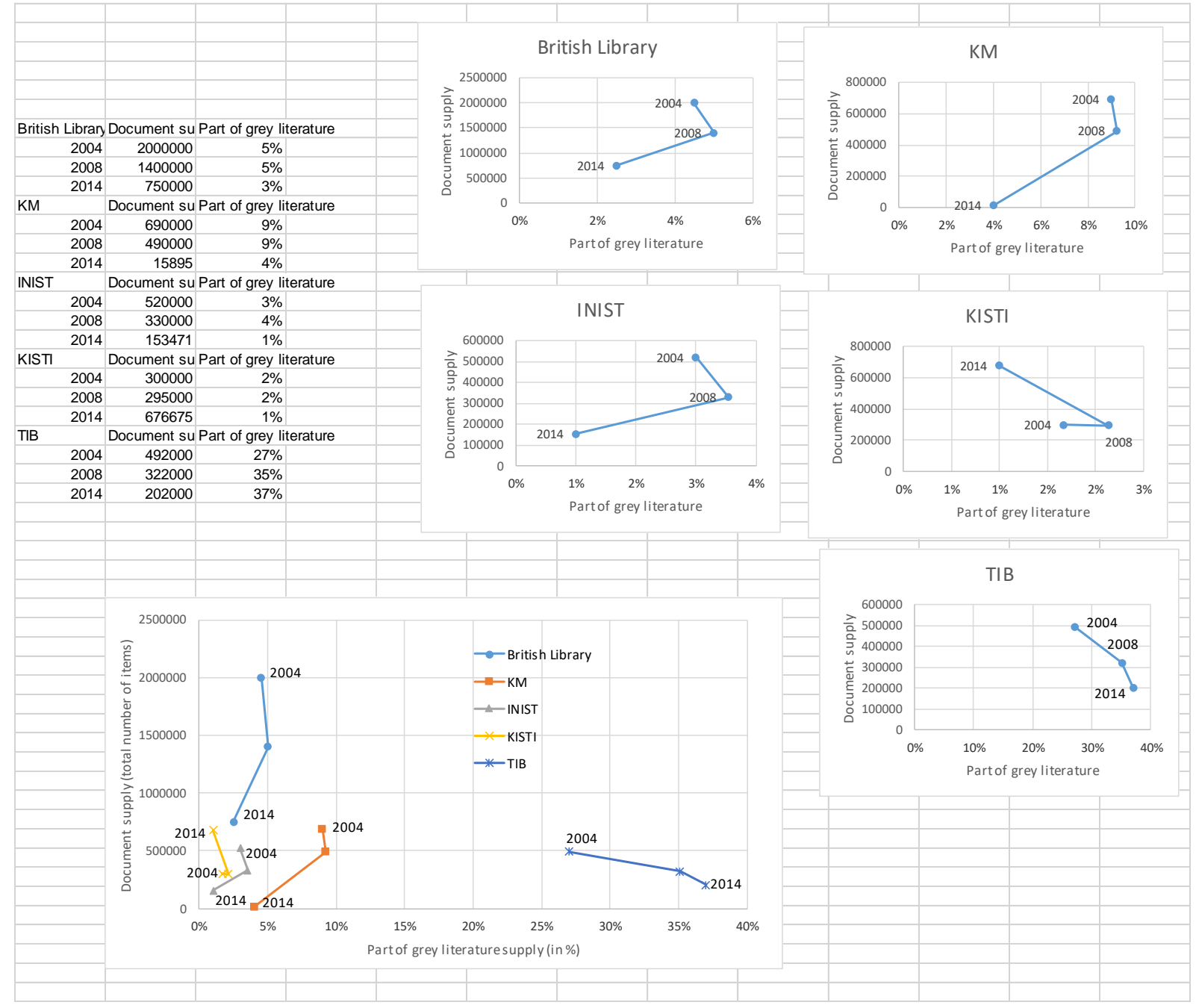

Figure 1: Document supply and grey literature

Figure 1 presents the synthesis of real and estimated figures on document supply. Four institutions have low to medium-level supply with a low proportion of grey material (KM, INIST, KISTI, BL). The TIB has a medium-level supply with a significant proportion of grey material. Except for the TIB, the part of grey literature of the overall document supply decreased for all institutions between 2004 and 2014.

Open access

The five institutions continue to expand their open access strategies. Just as in 2004 and 2008, these strategies are specific and reflect institutional and national choices rather than global approaches. Yet, their strategies share two or three common or comparable projects, such as PubMed Central (BL and KM), national repositories (KM and KISTI), or attribution of DOIs to datasets, dissertations and other objects (BL, KM, INIST, TIB; KISTI is an affiliated member of DataCite).

Information system

According to the available information, the development of the document supply systems was primarily to maintain or adapt existing systems instead of changing them - except for KM where the former CISTI software was replaced by Infotrieve's Mobile Library software. 


\section{Strategic marketing}

Under specific conditions, each of the former "big five" document suppliers elaborated its own institutional answer to the critical questions of strategic management (Drucker 1954):

- "What is our business?" There is a general shift away from collection development to gateway functions and access management. Document supply is no longer a priority but is at best part of a global service with a focus on access to information and "content" 4 , mainly through open access but also through licensing (INIST). Providing and/or facilitating access to information appears to be the core business, with related issues: dissemination and valorisation of institutional (national) scientific output (KM, KISTI, TIB), knowledge management (KM) and long-term preservation of documents (BL).

- "Who are our customers?" Modern document supply is customer-centred, not service-centred, which implies good knowledge and a clear definition of the customers. During the last decade, at least three institutions (BL, KM and INIST) redefined their user communities, with a strong preference for domestic customers, in particular the national academic community (Higher Education and research), and a clear separation between the corporate and the public sector. Global aspirations are no longer put forward, if not abandoned.

- "What is our added value for customers?" Today, differences appear to outweigh shared values. Each institution develops a distinctive communication strategy to highlight its specific value proposal for the target user community. The only common asset seems to be guaranteed $100 \%$ legal compliance of their services and products, through copyright-cleared items and licensing. Two other assets, yet less common, are the shift from information to knowledge and the capacity of long-term preservation of research results.

- "Where should our business go?" A couple of years ago, we established a kind of wish-list for modern document supply, with items such as customizable search technology, e-commerce features, improved reporting, automation, re-engineering of the workflows, social media etc. (Schöpfel \& Gillet 2007). In fact, only one issue on this list appears to be part of the actual strategy of the major document suppliers, i.e. resource sharing and networking, especially on a national or regional level. Their own holdings, if not discontinued, are considered as part of the network, not as a core asset of the document supply service. The other dominant and shared strategic goals are not directly related to document supply, like research data management or text and data mining.

\section{Conclusion}

Transition is over, and choices have been made. Ten years ago, document supply was (still) a central part of scientific and technical information, dominated by public intermediation and the "big five" public institutions, with national roots but global ambitions. This time is gone. Ten years later, our survey reveals a shattered landscape, with two national libraries, two service providers in the national digital research infrastructures, and an integrated research, computer and STI centre, each institution pursuing a strategy that responds to its special environment. This environment may vary from one country to another but there seems to be some common features, such as budget cuts, legal barriers (copyright), focus on domestic needs and open access policies to foster dissemination and impact of research results. Document supply for corporate customers tends to become a B2B service

\footnotetext{
${ }^{44}$ See the recent strategy paper of the British Library (2015)
} 
while the delivery for the public sector relies more than before on resource sharing and networking with academic and public libraries.

Except perhaps for the TIB Hannover, the declining importance of grey literature points towards the changing role of these institutions mentioned above. Less intermediation, less acquisition and collection development; more high value services, more dissemination and preservation capacities designed for the scientific community needs (research excellence, open access, data management etc.). In the short term, this may not be satisfying for the nonconventional grey literature, because of problems with metadata, referencing, preservation and broken links. In the mid- and long-term, the semantic web, content mining tools and institutional repositories connected to current research information systems may provide a solution for grey literature. But this will no longer be document supply.

\section{Bibliography}

Appleyard, A. (2010), "British Library Document Supply - A Fork in the Road", Interlending \& Document Supply, Vol.38 No.1, pp. 12-16, available at http://dx.doi.org/10.1108/02641611011025307

Appleyard, A. (2015), "British Library Document Supply: An Information Service Fit for the Future", Interlending \& Document Supply, Vol. 43 No. 1, pp. 9-13. available at http://dx.doi.org/10.1108/ILDS-11-2014-0055

Boukacem-Zeghmouri, C. and Schöpfel, J. (2006), "Document Supply and Open Access: an International Survey on Grey Literature", Interlending \& Document Supply, Vol. 34 No. 3, pp. 96-104, available at http://archivesic.ccsd.cnrs.fr/sic_00181485/en/

Brammer, M. and Olf, J. (2014), "Current Developments in Document Delivery in Germany", Interlending \& Document Supply, Vol. 42 No. 2/3, p. 75-78, available at http://dx.doi.org/10.1108/ILDS-05-2014-0023

Brazier, C. (2012), "What did the Internet ever do for us? Changes in Collection Development and Management at the British Library, 2000-2012", Alexandria, Vol. 23 No. 3, available at http://manchester.metapress.com/content/u4822113p9555w28/

British Library (2014), Annual Report and Accounts 2013/14, The British Library, London, freely available at http://www.bl.uk/aboutus/annrep/2013to2014/annual-report2013-14.pdf

British Library (2015), Living Knowledge. The British Library 2015-2023, The British Library, London, freely available at http://www.bl.uk/projects/living-knowledge-thebritish-library-2015-2023

Drucker P. F. (1954), The Practice of Management, New York, Harper Collins.

Egan, I. and Stevens, R. (2011), "A Review of Pamphlet Treatments at the British Library - a Collaborative Approach, Journal of the Institute of Conservation, Vol. 34 No. 2, pp. 186201, available at http://www.tandfonline.com/doi/abs/10.1080/19455224.2011.609052

Franzkowiak, A. (2012), "Working with focus groups as a Post-Occupancy evaluation (POE) to support a re-launch of the library building of the German National Library of Science and Technology/University Library Hannover (TIB/UB)", In World Library and Information Congress. 78th IFLA General Conference and Assembly, 11-17 August 2012, Helsinki, Finland, freely available at http://conference.ifla.org/past-wlic/2012/190franzkowiak-en.pdf

Gillet, J. (2007), "The new secure electronic delivery service of INIST", In 73rd IFLA General Conference and Council, 96-1 Document Delivery and Resource Sharing Section (1), 19-23 August 2007, Durban, South Africa, freely available at http://citeseerx.ist.psu.edu/viewdoc/download?doi=10.1.1.150.9974\&rep=rep1\&type=pdf

Gillet, J. (2008), "Sharing resources, networking and document delivery: the INIST experience", Interlending \& Document Supply, Vol. 36 No. 4, pp. 196-202, available at http://dx.doi.org/10.1108/02641610810919534 
Gillet, J. (2014), “A Review of Interlending and Document Supply in France: 2014”, In Restructuring Resource Sharing: New Organizations, Technologies, Methods. IFLA Satellite Meeting, Nancy, 13-14 August 2014. Slide show freely available at: http://docdel.inist.fr/?Programme

Green, S. (2009), "The Digital Library Programme at the British Library: Goals and Priorities”, Interlending \& Document Supply, Vol. 37 No. 3, pp. 136-139, available at http://dx.doi.org/10.1108/02641610910985602

Johnson, G. J. (2011), "No fate but what we make? Current trends and challenges in the UK document supply community", Interlending \& Document Supply, Vol. 39 No. 3, pp. 127133, available at http://dx.doi.org/10.1108/02641611111164609

Hwang, H., Seonheui, C. and Hyesun, K. (2014), "Open Access Korea, phase 1: 5 years on (poster)", In GL16 Sixteenth International Conference on Grey Literature. Grey Literature Lobby: Engines and Requesters for Change. December 8-9, 2014, Library of Congress, Washington D.C., USA.

KISTI (2011), Login to New World of Information and R\&D Infra. KISTI Annual Report 2011, Korea Institute of Science and Technology Information, Daejeon, freely available at http://en.kisti.re.kr/blog/post/2011-kisti-annual-report/

Luca, H. and Koch, K. (2014), "Hochschulweite Kooperationen zur Förderung von Informationskompetenz - ein Praxisbericht der TIB/UB Hannover", In 103. Deutscher Bibliothekartag 2014, Bremen, slide show freely available at http://www.opusbayern.de/bib-info/volltexte/2014/1649/

McGrath, M. (2015), "IFLA Nancy and Lyon 2014: The Many Faces of Resource Sharing", Interlending \& Document Supply, Vol. 43 No. 1, available at http://dx.doi.org/10.1108/ilds-11-2014-0056

Meyer, T. (2009), "Die zentralen Fachbibliotheken und ihre Rolle für die Fachinformation in Deutschland", Berliner Handreichungen zur Bibliotheks- und Informationswissenschaft, Vol. 248, available at http://edoc.hu-berlin.de/series/berliner-handreichungen/2009248/PDF/248.pdf

Neumann, J. (2012), "Digitale Dienstleistungen an der TIB/UB Hannover - eine qualitative Erforschung der Nutzererwartungen", Berliner Handreichungen zur Bibliotheks- und Informationswissenschaft, Vol. 326, freely available at http://edoc.huberlin.de/series/berliner-handreichungen/2012-326/PDF/326.pdf

Rosemann, U. (2013), "Coming together - a model of integration for TIB and university library Hannover", In 34th Annual IATUL Conference, 15-18 April 2013, Cape Town, South Africa, freely available at http://docs.lib.purdue.edu/iatul/2013/papers/43/

Rosemann, U. and Brammer, M. (2010), "Development of Document Delivery by Libraries in Germany since 2003”, Interlending \& Document Supply, Vol. 38 No. 1, pp. 26-30, available at http://www.emeraldinsight.com/doi/full/10.1108/02641611011025334

Schöpfel, J. (2011), "Towards a Prague Definition of Grey Literature", In GL12 Twelfth International Conference on Grey Literature: Transparency in Grey Literature. Grey Tech Approaches to High Tech Issues. Prague, 6-7 December 2010, (pp. 11-26). Amsterdam: TextRelease, freely available at http://archivesic.ccsd.cnrs.fr/sic_00581570/fr/

Schöpfel, J. (2014), “Open access and document supply”, Interlending \& Document Supply, Vol. 42 No. 4, pp. 187-195, available at http://dx.doi.org/10.1108/ILDS-10-2014-0049

Schöpfel, J. and Gillet, J. (2007), "On document supply in the digital world", Interlending \& Document Supply, Vol. 35 No. 4, pp. 195-204, available at http://dx.doi.org/10.1108/02641610710837491

Schöpfel, J. and Prost, H. (2009), "Document Supply of Grey Literature and Open Access: an Update", Interlending \& Document Supply, Vol. 37 No. 4, pp. 181-191, available at http://archivesic.ccsd.cnrs.fr/sic_00460086 
Schöpfel, J. and Farace, D. J. (2010), "Grey Literature", In M. J. Bates and M. N. Maack (Eds.), Encyclopedia of Library and Information Sciences, Third Edition, pp. 2029-2039, London, CRC Press.

Schöpfel, J. and Gillet, J. (2011), "A review of interlending and document supply in France: 2010", Interlending \& Document Supply, Vol. 39 No. 2, pp. 76-83, available at http://dx.doi.org/10.1108/02641611111138860

Tessler, A. (2013), Economic Valuation of the British Library, Report, Oxford Economics, Oxford, freely available at http://tosca.vtlseurope.com:8098/arxius/pdf/E130253.pdf

Wilkinson, J. M., Pollard, T. and Farquhar, A. (2010), "British Library Dataset Programme: Supporting Research in the Library of the 21st Century", LIBER Quarterly, Vol. 20 No.1, pp. 94-104, freely available at http://liber.library.uu.nl/index.php/lq/article/view/7979

Yoo, S. (2010), "Document delivery through domestic and international collaborations: the KISTI practice", Interlending \& Document Supply, Vol. 38 No. 3, pp. 175-182, available at http://dx.doi.org/10.1108/02641611011072378

All web sites visited in January 2015. 